\title{
PERANCANGAN TATA LETAK FASILITAS LABORATORIUM PERAWATAN PESAWAT TERBANG
}

\author{
Eko Poerwanto \\ Sekolah Tinggi Teknologi Adisutjipto \\ J1 Janti Blok R Lanud Adisutipto Yogyakarta \\ ekoevtas@gmail.com
}

\section{ABSTRACT}

Each system installed in the aircraft requires high accuracy. Aircraft maintenance will be able to be reliable if all maintenance support needs ergonomically designed. One factor that is needed in the laboratory is an ergonomic layout needs good facilities. The layout of the facility that will support in improving the accuracy required in aircraft maintenance. The purpose of this study is to determine and organize work area and all the optimal aircraft maintenance facilities. The method used is to use the $A R C$ and the Work Sheet. Based on the results of the analysis using ARC and Work Sheet layout arrangement forms an ideal material for aircraft maintenance is fixed (fixed material location). While the treatment facility will be located around the main products,namelyplane that is on the floor is desired perawatan. Hope STTA as sound institutions may have facilities aerospace aircraft maintenance practices are sufficient.

Keywords: aircraft maintenance, facility layout, ARC.

\section{Pendahuluan}

Rancangan tata letak (lay out design) memegang peranan penting dalam efektifitas dan efisiensi tempatpelaksanaan praktek perawatan pesawat. Lay-out designadalah proses alokasi dan penataan ruangan serta peralatan pendukung produksi yang ditata sedemikian rupa sehingga pergerakan operator berlangsung seminimal mungkin.Seluruh luasan ruangan termanfaatkan, dan menciptakan rasa nyaman kepada operator yang bekerja serta obyek yang menerima pelayanan.Lay-out design praktek perawatan pesawat terbang perlu direncanakan secara matang sebelum tempat praktek dibangun dan tidak tertutup kemungkinan untuk direvisi dikemudian hari bila dinilai sudah tidak laik lagi.

Salah satu metode yang sesuai untuk digunakan untuk menilai suatu rancangan 
tata letak fasilitas adalah Activity

Relationship Chart (ARC) dengan

menggunakan tolok ukur derajat kedekatan

hubungan antara satu fasilitas

(departemen) dengan lainnya. Pada

dasarnya diagram ini menjelaskan

hubungan pola aliran pekerjaan dan lokasi

dari masing-masing departemen penunjang

terhadap departemen produksinya.

\section{Metode Penelitian}

Analisis yang digunakan untuk rancangan tata letak fasilitas adalah Activity Relationship Chart (ARC) dengan menggunakan tolok ukur derajat kedekatan hubungan antara satu fasilitas (departemen) dengan lainnya. Pada dasarnya diagram ini menjelaskan hubungan pola aliran pekerjaan dan lokasi dari masing-masing departemen penunjang terhadap departemen produksinya. Penelitian ini

a. Fasilitas Perawatan Pesawat Terbang Pada dasarnya fasilitas laboratorium perawatan pesawat harus memenuhi standar, sesuai Peraturan Menteri Perhubungan Nomor : KM 24 Tahun 1997 tanggal : 23 July 1997 dan SKEP/53/III/2001 dari Dirjen Perhubungan Udara, tentang Petunjuk Pelaksanaan (Staff InstructionNomor 147-

1) berkaitan Persetujuan Organisasi Pelatihan Perawatan Pesawat Udara (Aircraft Maintenance Training
Organization(AMTO) certificates issued pursuant to Civil Aviation Safety Regulations(CASR). Part 147.

Seluruh kegiatan yang ada pada perawatan pesawat tentunya akan membutuhkan fasilitas ruangan yang memadai. Beberapa ruang fasilitas untuk mendukung kegiatan tersebut adalah :

1. Lantai perawatan pesawat

2. Ruang manager teknik

3. Ruang Kabag. \& Kasi. Harian

4. Ruang Inspector

5. Ruang Mechanic (mahasiswa)

6. Ruang Tata Usaha Teknik (TUT).

7. Ruang Publikasi Teknik

8. Ruang Perlengkapan

9. Ruang Work Shop Lisment (Listrik \&Instrument)

10. Ruang Work Shop Avionic.

11. Ruang Work Shop Hyd./ Pneumatic

12. Ruang Work Shop Battery

13. Ruang GSE (Ground Support

Equipment)

14. Ruang Tools.

15. Ruang Gudang Materiil.

16. Tempat di luar hangga untuk Ground Run (Appron)

17.Rest Room

\section{2.Activity Relationship Chart (ARC)} pada Perawatan Pesawat Terbang

Kebutuhan fasilitas perawatan pesawat terbang berkaitan dengan aktivitas 
pemeliharaan yang dilakukan adalah sebagai berikut :

1. Berdasarkan identifikasi fasilitas perawatan pesawat terbang seperti di atas, maka ada 17 fasilitas yang akan diidentifikasi keterkaitannya antara yang satu dengan yang lainnya.

2. Berdasarkan urutan proses perawatan pesawat terbang, maka dapat ada beberapa jenis aktivitas utama, yaitu : proses persiapan, proses inspeksi, proses perbaikan, proses inspeksi hasil perbaikan, proses pengetesan, dan proses (administrasi \& finishing).

3. Setelah mengidentifikasi seluruh proses yang dilakukan pada perawatan pesawat, maka dapat didefinisikan kriteria hubungan antar departemen / fasilitas perawatan pesawat terbang yang satu dengan fasilitas yang lainnya. Kriteria hubungan yang ditetapkan berdasarkan kriteria sebagai berikut : (A) = Mutlak perlu didekatkan; $(\mathrm{E})=$ Sangat penting untuk didekatkan, (I) = Penting untuk didekatkan; $(\mathrm{O})$ = Cukup / biasa; $(\mathrm{U})=$ Tidak penting; $(\mathrm{X})$ = Tidak dikehendaki berdekatan.

4. Mengadakan penilaian hubungan aktivitas yang telah dipetakan tersebut dengan kenyataan dasar manajemen. Secara bebas beri kesempatan untuk evaluasi atau perubahan yang lebih sesuai.
2. 3. Penentuan Tata Letak Fasilitas

Berdasarkan Kriteria

Berdasarkan aktivitas perawatan pesawat terbang di dalam hangar perawatan, maka dapat ditentukan keterkaiatan hubungan antar aktivitas perawatan pesawat dengan deskripsi alasan sebagai berikut :

Tabel 1.Deskripsi Alasan Keterkaitan Antar Aktivitas Perawatan Pesawat Terbang

\begin{tabular}{|c|l|}
\hline $\begin{array}{c}\text { Kode } \\
\text { Alasan }\end{array}$ & \multicolumn{1}{|c|}{ Deskripsi Alasan } \\
\hline 1. & $\begin{array}{l}\text { Penggunaan catatan secara } \\
\text { bersama }\end{array}$ \\
\hline 2. & $\begin{array}{l}\text { Menggunakan tenaga kerja yang } \\
\text { sama }\end{array}$ \\
\hline 3. & $\begin{array}{l}\text { Menggunakan space area yang } \\
\text { sama }\end{array}$ \\
\hline 4. & $\begin{array}{l}\text { Derajat kontak personil yang } \\
\text { sering dilakukan }\end{array}$ \\
\hline 5. & $\begin{array}{l}\text { Derajat kontak kertas kerja yang } \\
\text { sering dilakukan }\end{array}$ \\
\hline 6. & Urutan aliran kerja \\
\hline 7. & $\begin{array}{l}\text { Melaksanakan kegiatan kerja } \\
\text { yang sama. }\end{array}$ \\
\hline 8. & $\begin{array}{l}\text { Menggunakan peralatan kerja } \\
\text { yang sama. }\end{array}$ \\
\hline 9. & $\begin{array}{l}\text { Kemungkinan bau, bising, } \\
\text { getaran yang tidak } \\
\text { mengenakkan, dan lain-lainnya }\end{array}$ \\
\hline
\end{tabular}

Tabel 2. Kriteria Keterkaitan Antar Aktivitas Perawatan Pesawat Terbang

\begin{tabular}{|c|l|}
\hline Kode & \multicolumn{1}{|c|}{ Derajat hubungan } \\
\hline A & Mutlak perlu didekatkan \\
\hline E & $\begin{array}{l}\text { Sangat penting untuk } \\
\text { didekatkan }\end{array}$ \\
\hline I & Penting untuk didekatkan \\
\hline O & Cukup / biasa \\
\hline U & Tidak Penting \\
\hline X & Tidak dikehendaki berdekatan \\
\hline
\end{tabular}

2. 4. Pengacuan Pustaka

Tata letak fasilitas akan mempunyai peran meningkatkan produktivitas dengan 
meningkatkan efisiensi pada biaya pemindahan bahan, sesuai dengan penelitian yang dilakukan (Yuriyanto, 2009) bahwa analisis terhadap layout awal dan layout usulan menunjukkan bahwa terdapat perbaikan tata letak yang cukup signifikan dari segi waktu, biaya dan momen perpindahan. Ditinjau dari segi waktu pemindahan bahan, terjadi penurunan waktu sebesar $34,73 \%$, dari segi momen perpindahan terjadi penurunan sebesar 37,15\%. Ditinjau dari segi biaya, terjadi penurunan biaya pemindahan bahan sebesar 37,67\%. Keserasian atau keseimbangan pada perancangan tata letak fasilitas akan meningkatkan kualitas hidup secara keseluruhan, baik fisik maupun mental (Kosterman, 2007).

Esa M. Rantanen dan kawan-kawan (2003) mengadakan penelitian yang berjudul "Human Factors Considerations in The Design of an Aircraft Maintenance Hangar". Penelitian memfokuskan pada aspek Human Factors yang melibatkan antara instrruktur/pelatih dan siswanya, serta fasilitas pendukung lainnya yang diperlukan pada perawatan pesawat terbang.Kegiatan perawatan pesawat terbang memerlukan koordinasi semua lini dengan prosedur yang terstandart.Hal ini dilakukan supaya mengurangi faktor kesalahan yang sering terjadi pada keterlibatan manusia di dalamnya (Human Error), karena perawatan pesawat terbang membutuhkan tingkat keselamatan yang tinggi.

Penelitian ini menganalisis hubungan aktiitas yang dilakukan operator dan peralatan pendukung kerja antara satu fasilitas dengan fasilitas perawatan pesawat yang lainnya, mengingat kedekatan aktivitas dapat meningkatkan efektivitas kerja. Jenis tata letakuntuk perawatan pesawat umumnyabersifat material tetap (fixed material location). Untuktata letak fasilitas yang berdasarkan posisi tetap ini, material atau komponen produk yangutamanya akan tinggal tetap pada posisi/ lokasinya, sedangkan fasilitas produksi sepertitools, mesin, manusia serta komponen-komponen kecil lainnya akan bergerak menujulokasi material atau komponen produk utama tersebut. Kedekatan fasilitas yang satudengan yang lainnya inilah yang perlu menjadi bahan pertimbangan dalam menyusun tataletak fasilitas untuk tipe ini.

\section{Hasil dan Pembahasan}

Kedekatan antar fasilitas perawatan pesawat terbang dilakukan dengan alasan yang sudah ditentukan berdasarkan kenyataan aktivitas di lapangan. Berdasarkan hal tersebut disusun work sheet sebagai berikut :

\section{Tabel 3.Work Sheet Activity Relationship Fasilitas Pemeliharaan Pesawat}




\begin{tabular}{|c|c|c|c|c|c|c|c|}
\hline \multirow{2}{*}{ No. } & \multirow{2}{*}{ Fasilitas / Bagian / Departemen } & \multicolumn{6}{|c|}{ Derajat Kedekatan } \\
\hline & & A & E & I & 0 & $\mathrm{U}$ & $\mathrm{x}$ \\
\hline 1 & Lantai perawatan pesarwat & $\begin{array}{l}2,3,4,5,6,7,8,9 \\
1,0,11,1,12,13 \\
14,15,16\end{array}$ & & & 17 & & \\
\hline 2 & Ruang manager teknik & 1 & $\begin{array}{l}3,4,5, \\
6,14\end{array}$ & \begin{tabular}{|l|}
$7,8,9$ \\
$10,11,12$, \\
$13,14,16,17$
\end{tabular} & & & \\
\hline 3 & Ruang Kabag. \& Kasi. Har. & 1,7 & 15 & \begin{tabular}{|l}
$4,5,6,6,9$, \\
$10,11,12$ \\
16,17
\end{tabular} & & & \\
\hline 4 & Ruang Inspector & 1,7 & $\begin{array}{l}2,5,9, \\
10,11, \\
121516\end{array}$ & $\begin{array}{l}6,17 \\
3,6,13 \\
14,17 \\
\end{array}$ & & & \\
\hline 5 & Ruang Mechanic (mahasiswa) & 1,7 & $\begin{array}{l}2,1,1,8,9 \\
2,4,1,1,2 \\
13,14,16\end{array}$ & $\begin{array}{l}3,6, \\
15,17\end{array}$ & & & \\
\hline 6 & Ruang Tata Usaha Teknik (TUT) & 1,7 & 2,15 & \begin{tabular}{|l|}
$3,4,5,8$, \\
$9,10,11$, \\
$12,14,16$
\end{tabular} & 13,17 & & \\
\hline 7 & Ruang Publikasi Teknik & $1,3,4,5,6$ & $\begin{array}{l}2,9,10, \\
11,12\end{array}$ & $13,15,16$ & 8,14, & & \\
\hline 8 & Ruang Perlengkapan & 1 & $\begin{array}{l}5,14 \\
16\end{array}$ & $\begin{array}{l}2,3,4,6, \\
9,10,11, \\
10,1,15\end{array}$ & 17 & & \\
\hline 9 & $\begin{array}{l}\text { Ruang Work Shop Lisment (Listrik \& } \\
\text { Instrument) }\end{array}$ & 1 & $\begin{array}{l}4,5,7,10, \\
11,12\end{array}$ & $\begin{array}{l}2,3,8,8 \\
13,14 \\
15,16\end{array}$ & 17 & & \\
\hline 10 & Ruang Work Shop Avionic & 1 & $\begin{array}{l}4,5,7, \\
9,11\end{array}$ & \begin{tabular}{|l|}
$2,3,6,8$, \\
$12,13,14$ \\
15,16
\end{tabular} & 17 & & \\
\hline 11 & Ruang Work Shop Hyd/ Pneumatic & 1 & $\begin{array}{l}4,5,7, \\
9,10\end{array}$ & $\begin{array}{l}2,3,6,8, \\
12,1,14, \\
1516\end{array}$ & 17 & & \\
\hline 12 & Ruang Work Shop Battery & 1 & 4.,5,7,9. & \begin{tabular}{|l|}
$2,3,6,8,8$ \\
$10,11,13$ \\
$14,15,16$ \\
\end{tabular} & 17 & & \\
\hline 13 & Ruang GSE & 1,16 & 5 & $\begin{array}{l}2,3,4,7,8,9, \\
10,11,12, \\
14,15\end{array}$ & 6 & & 17 \\
\hline 14 & Ruang Tools & 1 & 5,8 & $\begin{array}{l}1,3,4,6,6,9 \\
10,11,12, \\
13,15,16\end{array}$ & & & 17 \\
\hline 15 & Ruang Gudang Materil & 1 & $2,3,4,6$ & \begin{tabular}{|l|}
$5,7,7,8,10,10$ \\
11,121, \\
14,16
\end{tabular} & & & 17 \\
\hline 16 & $\begin{array}{l}\text { Tempat di luar hangga untulk Ground } \\
\text { Rum (Appron) }\end{array}$ & 1,13 & $4,5,8$ & $\begin{array}{l}2,3,6,6,9, \\
10,11,12, \\
14,15\end{array}$ & & & 17 \\
\hline 17 & Rest Room & & & $2,3,4,5$ & \begin{tabular}{|l|}
$6,7,8,9$ \\
$10,11.12$
\end{tabular} & & $\begin{array}{l}13,14 \\
15,16\end{array}$ \\
\hline
\end{tabular}

Tabel diatas memperlihatkan bahwa posisi pesawat yang dirawat harus "Mutlak" didekatkan dengan fasilitas pendukung pada perawatan pesawat terbang.Ruang Mechanic dalam hal ini adalah mahasiswa yang detraining harus berdekatan dengan Ruang Publikasi Teknik yang berisi dokumen perawatan pesawat yang harus dikuasai oleh mahasiswa.

Berdasarkan alasan kedekatan antar fasilitas perawatan pesawat terbang dan kriteria keterkaitan aktivitas, maka analisis keterkaitan antar fasilitas perawatan pesawat dapat dibuatkan ARC sebagai berikut :

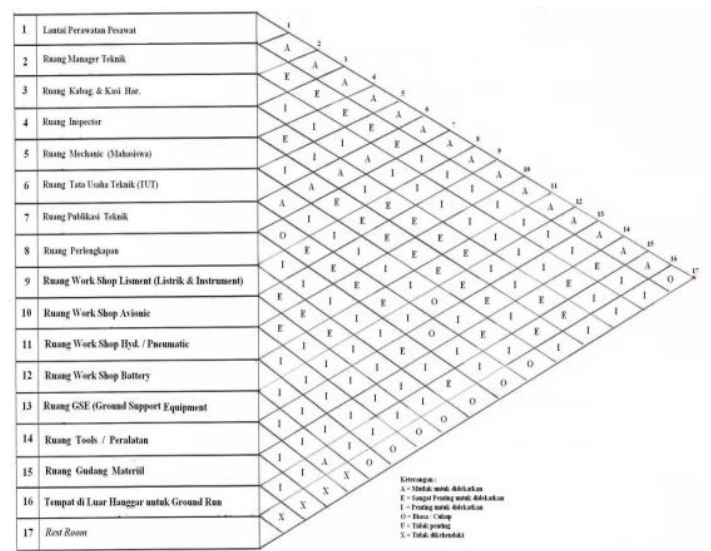

Gambar 1.Activity Relationship Chart (ARC) Fasilitas Perawatan Pesawat Terbang

Berdasarkan data yang diperoleh dari activity relationship chart dan work sheetnya, maka disusunlah rancangan tata letak fasilitas perawatan pesawat terbang yang mendekati kondisi ideal seperti di bawah ini :

Laboratorium Perawatan Pesawat Terbang STTA Yogyakarta

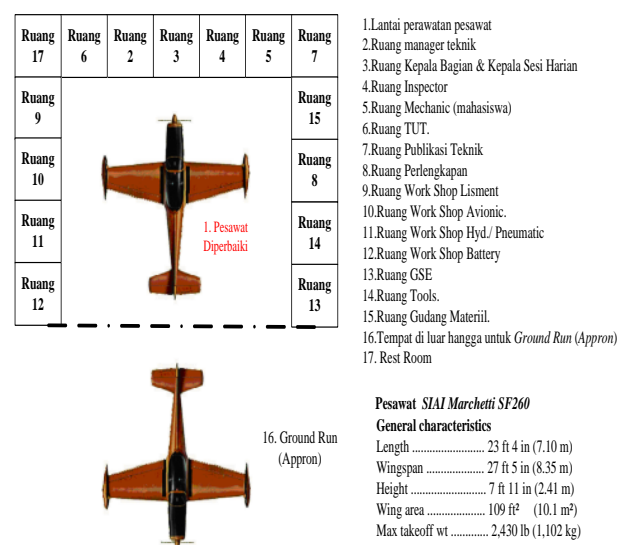

Gambar 2. Rancangan Tata Letak Fasilitas Laboratorium Perawatan Pesawat Terbang

Berdasarkan ARC dan Work Sheet serta rancangan tata letak fasilitas di atas dapat dianalisis bahwa tata letak fasilitas perawatan "Mutlak" harus didekatkan 
dengan lantai perawatan pesawat, karena bentuk susunan layout ideal untuk perawatan pesawat adalah material tetap (fixed material location). Sedangkan fasilitas perawatan akan berada mengelilingi produk utamanya, yaitu pesawat yang berada pada perawatan.

Kegiatan Ground-Run adalah pekerjaan yang dilakukan setelah pesawat terbang selesai dipelihara kemudian dilakukan uji fungsi pada semua sistem yang ada pada pesawat terbang.Kegiatan ini harus dilakukan di luar hangar (appron), karena mesin pesawat akan dihidupkan sehingga menimbulkan kebisingan yang sangat mengganggu.

\section{KeSimpulan}

Berdasarkan hasil dan pembahasan rancangan fasilitas laboratorium perawatan pesawat terbang dengan menggunakan analisis keterkaitan hubungan antar aktivitas kegiatan perawatan pesawat terbang, maka dapat disimpulkan sebagai berikut :

1. Activity Relationship Chart (ARC) cukup memadai untuk digunakan dalam menentukan tata letak fasilitas perawatan pesawat terbang.

2. Tata letak fasilitas praktek perawatan pesawat terbang yang baik dapat meningkatkan aspek ergonomi bagi seluruh mahasiswa (operator) yang melaksanakannya, sehingga posisinya harus selalu berdekatan dengan pembimbingnya, dalam hal ini Inspector.

3. Kekurangan penelitian ini belum memperhatikan aspek kebisingan berkaitan dengan fasilitas yang lain di suatu Kampus.

\section{SARAN}

Hasil penelitian ini dapat digunakan bagi institusi (STTA) dalam merencanakan fasilitas praktek perawatan pesawat terbang. Sedangkan saran untuk untuk penelitian lebih lanjutadalah menambahkan faktor kebisingan berkaitan dengan tata letak fasilitas secara menyeluruh yaitu fasilitas yang lainnya di dalam area kampus, karena aktivitas Ground-Run yang harus dilakukan pada perawatan pesawat terbang akan menimbulkan tingkat kebisingan yang tinggi.

\section{UCAPAN TERIMA KASIH}

Penulis mengucapkan terima kasih kepada Bapak Darmatmo, SE yang telah memberi dukungan pengetahuan berkaitan fasilitas suatu perawatan pesawat terbang, sehingga hasil penelitian ini dapat digunakan sebagai tambahan pengetahuan.

\section{DAFTAR PUSTAKA}

Apple, James M., (1990) Tata Letak Pabrik dan Pemindahan Bahan, 
Edisi Ketiga, Penerbit ITB, Bandung.

Arikunto, Suharsimi, (2002) Prosedur Penelitian: Suatu Pendekatan Praktek, Edisi Revisi V, PT. Rineka Cipta, Jakarta.

Balakrishnan, Jaydeep, Chun Hung Cheng, and Daniel G. Conway, (2000), An Improved Pairwise Exchange Heuristic for the Dynamic Plant Layout Problem, International Journal of Production Research.

Darmatmo, (2007).,Diktat Aircraft Maintenance., STTA Yogyakarta.

Esa M.R.,Thomas A.B., David S.W., Mathew S.H.,Yusef O.E., and Michelle L.W. (2003), Human Factors Conciderations in The Design of An Aircraft Maintenance Hangar, Proceedings of the 47th. Annual Meeting of the Human Factors and Ergonomics Society, Santa Monica.

Francis, Richard L., Leon F. McGinnis, Jr., and John A. White, (1992), Facility Layout and Location: An Analytical Approach, Edisi Kedua, Prentice-Hall, Inc.,New Jersey.

Kosterman, (2007), Desain Tata Letak Penempatan Alat Kedokteran GigiDental Device Layout Design, Bagian Ilmu dan Teknologi Kedokteran Gigi Fakultas Kedokteran Gigi Universitas Padjadjaran.

Moore, James M., (1962) Plant Layout and Design, The Macmillan Company, New York.

$\begin{array}{ccr}\text { SKEP/53/III/2001 } & \text { dari } & \text { Dirjen } \\ \begin{array}{ccr}\text { Perhubungan } \\ \text { Petunjuk }\end{array} & \text { Udara, } & \text { tentang } \\ \text { Instruction } & \text { Nomoran } & \text { (Staff } \\ 147-1)\end{array}$

berkaitan Persetujuan Organisasi Pelatihan Perawatan Pesawat Udara (Aircraft Maintenance Training Organization (AMTO)certificates issued pursuant to Civil Aviation Safety Regulations (CASR). Part 147.

Wignjosoebroto, S., 2003, Tata Letak Pabrik dan Pemindahan Bahan, Guna Widya.

Wignjosoebroto, S., Rahman, A., dan Pramono, D.(2006), Perancangan Lingkungan Kerjadan Alat Bantu yang Ergonomis untuk Mengurangi Masalah Back Injury danTingkat Kecelakaan Kerja pada Departemen Mesin Bubut (Studi Kasus PT AtakIndometal Ngingas Waru-Sidoarjo).

Yuriyanto, (2009).,Perancangan Ulang Tata Letak Lantai Produksi dengan MenggunakanMetode Pairwise Exchange di PT. Cahaya Kawi Ultra Polyintraco, Tugas AkhirDepartemen Teknik Industri Fakultas Teknik USU Medan. 